\title{
LONDON, ENGLAND AND BEYOND: SOCIAL TRANSFORMATIONS IN RICHARD BROME'S THE SPARAGUS GARDEN
}

\begin{abstract}
Richard Brome's The Sparagus Garden (1635) unfolds against the backdrop of the rapidly transforming urban and social landscapes of Caroline London. This paper argues that this play is deeply implicated in the discursive processes of appropriating and understanding London's shifting urban and social topographies. Abounding with topical and topographical allusions, the play has long drawn critical interest mainly for its documentary qualities and its exploitation of the short-lived theatrical vogue for 'place-realism'. Spatial mobility, changes in the city's urban landscape and the play's insistent questioning of fundamental categories of social status, belonging and identity have taken centre stage, as critics have acknowledged that the play addresses and negotiates pressing anxieties of a society in flux.
\end{abstract}

Keywords: Richard Brome, Caroline drama, The Sparagus Garden, London, London comedy, place-realism, identity

Słowa kluczowe: Richard Bromte, dramat karoliński, The Sparagus Garden, Londyn, komedia londyńska, realizm miejsca, tożsamość

In the second act of Richard Brome's The Sparagus Garden (1635), the childless Londoner Rebecca Brittleware lists leisure activities she longs for. These, she argues, will work as a preliminary to getting pregnant. In particular, she "long[s] to see a play, and above all plays The Knight of the Burning — what d'ye call't?" Sir Hugh Moneylacks takes up the cue and completes the obvious title of the play: The Knight of the Burning Pestle (SG, 2.1. speeches 199-200). This is followed by a string of bawdry occasioned by the 
near-homophones "pestle" and "pizzle" (see SG, speech 201, n7180). ${ }^{1}$ On the surface, the exchange between Rebecca and Sir Hugh provides yet another occasion to indulge in sexual innuendo, but underneath the textual surface it branches out into several cultural, social and historical layers.

The audience of The Sparagus Garden witnessed a character in a play, set in London, referring to another play set in London, which had premiered roughly 30 years earlier, in 1607, and which had been revived shortly before the first performance of Brome's play in 1635. Francis Beaumont's The Knight of the Burning Pestle had been acted by a rivalling company at the Cockpit in Drury Lane; it must have been successful enough for Brome to briefly indulge in a stage character (and the audience) to pause and knowingly complete the title (see SG, 2.1. speech 199, n.7179). In The Sparagus Garden, theatrical in-jokes (often in the form of doubles entendres) indicate other sites of cultural production, in keeping with the tradition of city comedy. The in-jokes are being shared among the fictional characters on stage and between the characters and the audience - those 'in the know.' Conversely, those who were not aware of the theatrical fashions and conventions alluded to would be effectively marked off as unsophisticated and lacking in taste.

This meta-dramatic strategy of referencing a play that was being successfully performed at a nearby competing playhouse throws into relief Caroline theatre's role in the creation and the processing of London's cultural topography in the 1630s. Old and new urban places and spaces were being discussed and redefined both inside the theatres — in plays old and new — and outside them. The 'town', the area between the Western city wall and the court at Whitehall, became one of the major areas of change, development and cultural inscription. One of these spaces which invited discursive explorations was the underdeveloped space of Covent Garden, which had been a productive convent garden until 1536 and started to evolve into a neighbourhood for the status-conscious in the 1630s (see Zucker, 2011, pp. 110-118). In his analysis of the social and topographical reconfigurations Covent Garden and its surroundings were undergoing at the time, Adam Zucker emphasises the role of the theatre which he describes as a "distribution hub for the kinds of status and power structured by cultural competencies" (2011, pp. 109-110). Coming to see The Sparagus Garden or other plays staged at the hall theatres, the audience would traverse the evolving neighbourhood of

1 If not indicated otherwise, all quotations from The Sparagus Garden have been taken from: R. Brome, The Sparagus Garden, [modern text]. Ed. J. Sanders. Richard Brome Online. Retrieved from http://www. hrionline.ac.uk/brome [accessed 24.02.2017]. The quotes and references to the texts are in keeping with the citation guide of the Richard Brome Online project (https://www.hrionline.ac.uk/brome/copy. jsp - accessed 24.02.2017). 
the playhouses. Moving and viewing, they would participate in the process of defining the new urban space of the town.

The Sparagus Garden was first performed at Salisbury Court Theatre, which had opened in Whitefriars in 1629 and was the last of the fashionable indoor playhouses to open before theatrical activities were suspended in September 1642 (see Gurr, 2004, p. 37). ${ }^{2}$ The play was a tremendous success, even though Brome's own estimation of the profits - the enormous amount of $f_{1}, 000$ - was probably a crude exaggeration. Still, the play's success was impressive enough for a formal contract between the theatre and Brome. In this contract, Brome committed himself to write exclusively for the Salisbury Court company for a period of three years (see Steggle, 2004, pp. 67-68). ${ }^{3}$

Set in London, the play's fast-paced intrigue stages a host of characters, most of whom seem to be related to one another, either through the ties of family and kinship or by necessity, living cheek by jowl with each other in a densely populated neighbourhood. The childless Brittlewares rent out rooms to Sir Hugh Moneylacks, the aptly named knight whose financial sources have dried up and left him to his shifts. Sir Hugh is the son-in-law of old Striker and the natural father of young Annabel; he has been forced to give up Annabel to her grandfather in order to ensure her portion. Rebecca Brittleware's aunt Friswood has been in Striker's services for decades - and her services have been of a very comprehensive nature, since she acted both the role of a nurse to Annabel and that of a servant and lover to the widowed Striker. Economically, the characters are also greatly dependent on each other: Sir Hugh drags his landlord into his dubious schemes by which the impoverished knight partially makes a living: He fleeces young country bumpkins whose aspirations to the status of gentleman have driven them to London. Aided by his brothers-in-deceit, Sir Hugh pretends to acquaint the naïve former country dwellers with the fashions and bodily deportment, manners and tastes of a gentleman. In short, Sir Hugh pretends to sell them the cultural capital he disposes of. The hapless young countryman to be fleeced is Timothy Hoyden, who turns out to be the illegitimate offspring of Touchwood and Striker's long-deceased sister. This unhappy relationship, which dates back twenty-five years, is at the root of the continuous animosity between the now aged Justices of the Peace, Striker and Touchwood. At the end of the play, light has been shed on long-hid family secrets, an anonymous paternity has been discovered, long-standing animosities have been cleared and even

\footnotetext{
Martin Butler provides a detailed account of the establishment, development and eventful history of the Salisbury Court theatre in his essay (2006, pp. 97-128).

3 Matthew Steggle provides a detailed account of Brome's contract with the Salisbury Court, the conditions set down therein and the ensuing legal dispute between Brome and the company, about plays that had not been delivered and weekly remunerations that had been withheld (Steggle, 2004, pp. 67-71).
} 
the newly-arrived man from the countryside has turned out to have his origins in the tightly-knit London community of Brome's play. The (a)sparagus garden flaunted in the title turns out to be the locale where all the different plot lines meet and intersect in act three. In the garden, almost all the characters of the play are brought into contact, and like a catalyst the garden and the culinary and sexual pleasures it offers propel the intrigue and the characters towards the fast-approaching resolution.

\section{The Dramatic Landscape}

In the same way that the changing world of Jacobean London had offered fertile subject matter to its dramatists, Caroline London and its burgeoning and ever-shifting urban landscape continued to provide the cues to a myriad of plays. In these plays, newly emerging fashionable locales were placed alongside firmly established spaces, traditional long-standing urban communities were juxtaposed with neighbourhoods in the process of growing fashionable. All of these provided settings of the plays as well as considerable inspiration for the plots of a large variety of drama conveniently subsumed into the changing genre of city comedy. Corresponding to the ever-diversifying city, Brome's stage representations of Caroline London are nuanced and finely tuned in their depictions of specific urban communities and areas transforming themselves under the eyes of the spectators.

The experience of a growing urban agglomeration subjected to ongoing processes of transformation is at the heart of a large host of texts produced in the sixteenth and seventeenth centuries. This experience "is not simply 'reflected' in the works in question but inhabits their very forms" (Manley, 1995, p. 2), effectively banishing elements containing magic and romance which were no longer deemed as "viable frameworks for the representation of the city" (Manley, 1995, p. 433; see also Joachim Frenk's essay in this volume). Instead, city comedy obviously exposed and exploited the dramatic potential offered by a busy, buzzing town whose vivacity, burgeoning economy and possibilities to move socially up- or spectacularly downwards served as the backdrop to the plays' racy intrigues and characters. The intrigues registered and were driven by the tensions of seemingly diametrically opposed forces at work in the metropolis itself. The dramatists probed the popular myth of the city's potential "to incorporate and unify" its residents without regard to their social status, profession and motivations without casting aside the growing anxieties caused by the "prolific heterogeneity" that London brought forth (see Manley, 1995, pp. 433-436).

Yet, as the seventeenth century moved on into the 1620s and '30s, the struggling impulses which were at the heart of the genre seemed to be gradually wearing off. One 
of the reasons for this new tendency might be the emergence of the above-mentioned 'town' in the West End and its transformation into the "permanent, fashionable centre for England's elite" (Manley, p. 484), which was accompanied by tentative discursive productions of a 'metropolitan' way of life "where new forms of metropolitan organization and new traits in its individualized subjects were emerging in mutual genesis" (Manley, p. 485). Manley suggests that most of the London comedies written during the Caroline period (especially those written in the 1630s) revert to patterns of romantic comedy, turning the plot into a means to celebrate society's rejuvenation and the reconciliation of contending factions. ${ }^{4}$ Interestingly, Manley explicitly points, among other plays, to Brome's The Sparagus Garden, which he claims uses its settings, emerging new London locales, as a mere backdrop to stage processes leading to reconciliation and intermarriage between members of different social groups. ${ }^{5}$ This reading of The Sparagus Garden, and, by extension, of Caroline London comedy has come to be regarded as somewhat reductive in recent critical debates, even though most scholars admit that a change in tone and mood is perceptible in the late offshoots of city comedy. For instance, changing perspectives on polite manners and the desirability of acquiring the cultural capital which was required to move smoothly among and across the various social strata made themselves felt for instance in the conceptualisation of 'wit.' In Jacobean city comedy, 'wit' usually translated into the hero's or heroine's capacity to climb in the social hierarchy by tricking and cheating the other characters. In contrast to this essentially dubious quality of 'wit,' Caroline dramatists began to probe into "wit' as a social value" indicative of a character's accomplishment and up-bringing (Butler, 1984, p. 159).

\section{Moving West - Brome’s Changing London}

In the two decades preceding the closure of the public theatres in 1642, early modern London underwent major physical and social transformations. One of these changes occurred in the sparsely developed stretch of land between the City of London and

4 The term "London comedy," used most consistently by Jean Howard in her study Theater of a City: The Places of London Comedy 1598-1642 (2007) will be adopted here. Howard calls convincingly for a broader concept which could accommodate the great variety of comedies set in London and dealing with its non-aristocratic inhabitants rubbing shoulders in the economically and culturally burgeoning city. She suggests to refer to the works set in or deeply engaging with the changing metropolis as "London comed[ies]," which were popular "well into the 1630s" and "negotiated many more urban places than simply the city's shops and more urban issues than just those involving a shift to a placeless market economy" (Howard, 2007, p. 22).

5 The garden site, in Manley's account, is no more than "the polite backdrop for reconciliation and intermarriage between dignified merchants and gentry." (Manley, 1995, p. 476). 
the royal courts at Whitehall. According to Roy Porter, the City of London "remained a social mishmash of wealthy, middling and poor jostling wherever mazes of backyards and blind alleys led off main streets." However, "the westward drift of superior crafts," (Porter, 1996, p. 45) ushered in by the arrival of the Stuart court(s), permanently changed the physical appearance and social set-up of the Strand, the area's main thoroughfare. Having already set in during the latter end of the Tudor reign, this westward movement was propelled by the growth of the courts as well as the sheer purchasing power and desire for consumption of the royal households and their attendants and hangers-on. ${ }^{6}$ Many of those settled beyond the old walled city and sparked off the development of a site which had remained a rather rural area until then (see Porter, 1996, pp. 68-69). The Strand was gradually turned into a prestigious and highly fashionable residential area. One of its most conspicuous transformations took place from 1631 onwards, when the $4^{\text {th }}$ Earl of Bedford commissioned an architectural ensemble in the former Convent Garden to be built in the Italian manner, with a grand Piazza surrounded by arcaded houses that were soon coveted by courtiers and wealthy merchants (see Porter, 1996, pp. 70-71; Van Renen, 2011, p. 36). With regard to London comedy and the cityscape staged or referenced by Caroline playwrights,

London in the 1630s implies the Strand, not Cheapside, and the motives to action are less commercial than amorous, so although London comedy is still a serious form, the vices it castigates are promiscuity and pride rather than greed, and its yardstick is civilized behaviour rather than human kindness. (Butler, 1984, p. 158)

However, the new area surrounding the Strand, 'the town,' was not so much thought of as a specific, material place consisting of a particular set of buildings, streets and squares. It was rather a symbolic concept useful for understanding certain developments and transformations which contemporaries were hard-pressed to make sense of. ${ }^{7}$ Staging extant and emerging London spaces, the fictional plots of London comedy appealed to the audience's sense of immediacy and topicality. At the same time, the plays addressed their spectators' anxieties and doubts, frequently treading a fine line between embracing change and novelty and simultaneously offering means of containment.

Looking at London comedies from over four decades, Jean Howard unravels the fertile relationship between the actual London places, their fictitious representations

6 On the new forms and staggering scale of consumption the early Stuart monarchs and their courtly circles indulged in, see for instance: Peck, 2000, pp. 268-289.

7 In his chapter "Covent Garden: Town Culture and the Location of Wit" Adam Zucker unpacks the various sets of meanings of the Town and its "symbolic co-signs in early modern social theory, the Country, the City, and the Court" (2011, pp. 106-108). 
on the sundry stages within the well-known, albeit constantly morphing framework of London comedy, and the potential impact the theatrical representations had on their spectators' understanding of their urban environments:

[P]laywrights imaginatively transformed urban places into settings for specific kinds of social interaction, whether between a citizen and an alien, a debtor and a creditor, a prostitute and a client, or a dancing master and a country gentleman. As represented on the stage, the places of London thus became a powerful resource in complex and socially significant renditions of urban life. (Howard, 2007, p. 3)

Tying in with Howard's reading, Julie Sanders stresses the agency of early modern drama "in the production and the practice of space" (2010, n.pag., 7). Polyvocal in their representations of London and its inhabitants, the plays drew their spectators into complex processes of meaning production: they drew on and simultaneously shaped their audience's perception of and responses to the newly-emerging London locales. ${ }^{8}$ Unsurprisingly, the westward expansion of the city proved a treasure-trove for playwrights who were fast to shift their preferred settings "from places within the old walled city to the fashionable venues of the West End" (Howard, 2007, p. 210). During the early 1630s, a whole range of comedies was set in or around the new town and its recently opened, fashionable places and parks. ${ }^{9}$

In terms of socio-political dynamics, the evolving new urban spaces in and around the Strand expanded the traditional trinity of court, city and country by a fourth element, the town (see Butler, 1984, p. 141), ${ }^{10}$ hinting at "at fluctuating relations between court, Parliament and City" (Porter, 1996, p. 72). Processes of accommodation

8 Various aspects of the agency of drama in the production of early modern London and its sociopolitical landscapes have been emphasised by numerous critics writing before and after Howard, for instance Butler, 1984, p. 281; Grantley, 2008, pp. 21-23; Sanders, 2010, n.pag., 7.

9 Theodore Miles (1942, pp. 428-429) is one of the first to suggest that this group of six Caroline plays testifies to a vogue for "realistic plays [...] which catered, demonstrably, to certain transitory interests of the seventeenth-century Londoner." The plays identified and grouped together by Miles are Shackerley Marmion's Holland's Leaguer (late 1631), James Shirley's Hyde Park (1632), followed later that year by Thomas Nabbes's Covent Garden and Richard Brome's The Weeding of Covent Garden, Nabbes's Tottenham Court (1633) and Brome's The Sparagus Garden (1635) which is often considered to be the latest of this particular group. Of course, this list refers only to those plays which reference the setting, or parts of the setting, in their titles (see Miles, 1942, pp. 428-440). Frieder Stadtfeld (1977, p. 17) identifies the following elements as crucial to the place-realism sub-genre: "one or all of the plays' main characters are portrayed in one or (rarely several) existent locales which are open to the public and in or around London" [translated by Ch. M.].

10 For a detailed analysis of the development of 'the town' and its implications for the Caroline variant of city comedy, see in particular Martin Butler's chapter "City Comedies: Courtiers and Gentlemen" in: Butler, 1984, pp. 141-180. 
and negotiation set in, which were soon to be incorporated into the dramatic output. In Butler's view, the playwrights composed comedies of social and political life, with intrigues focusing as much on socio-politics as on new fashions, manners and tastes which were evolving in these new environments. Notwithstanding their encompassing social scope, the plays simultaneously took great delight in anatomising the relationships which existed between the smaller units and the individual members of society (see Butler, 1984, pp. 141-143). The interest in local communities and neighbourhoods acknowledged the fact that a metropolis of the size of London "tend[s] to disaggregate into a mosaic of (sometimes overlapping) communities" (Boulton, 2000, p. 332; see also Sanders, 2011, pp. 178-181). In a city breaking any known mould, London's many micro-communities were crucial to their inhabitants, providing them with orientation and instigating processes of identity formation which foregrounded the local and the parochial. Many of the Caroline London comedies expanded their scope to unravel the nexus of pressing questions cutting across the social, economic, and political spheres. The inter- and intrapersonal dynamics which drive the characters and the plots of these comedies cannot be separated from the trans- and reformations of the characters' immediate urban and economic environments. Read against this background, Richard Brome's The Sparagus Garden foregrounds the social, economic and political energies which drive London in the mid-1630s.

\section{The Garden of (Earthly) Delights}

The long-standing critical tradition of qualifying and examining The Sparagus Garden as an example of the place-realism subgenre ${ }^{11}$ has been challenged by critics like Martin Butler, Matthew Steggle and Julie Sanders whose discussions of the play have amplified the scope of scholarly interest. Up to the early 1980s, readings of the play tended to focus on the marriage plot and on the reconciliation of the play's grappling social players. In these readings, the eponymous garden was relegated to the margins of critical interest, inhibiting the complex and often contending readings it allows for.

The garden was one of the new and popular resorts for the fashion-conscious and consumption-hungry London residents. Gardens specialising in the cultivation and sale of asparagus were being established in the 1630s. The first references to their existen-

11 G.E. Bentley for instance writes of Bromes's play that "The Sparagus Garden is basically a comedy of intrigue, like others of Brome's plays, but it was probably the farcical satire which, along with the garden scenes, made the play popular." (Bentley, 1956, p. 88). R.J. Kaufmann (1961) identifies, amongst others, the central motifs of the over-ambitious social climber, Brome's interest in and sensibility to regional dialects and his ability to exploit "the run of interest in place-realism" (p. 60) as crucial to account for the play's immense popularity (see Kaufmann, 1961, pp. 59-61). 
ce, according to Matthew Steggle, are to be found in the theatre, for instance in Philip Massinger's The City Madam (1632). The 'real-London' counterpart to Brome's asparagus garden was probably located on the south bank of the Thames, on a strip of reclaimed land in Lambeth Marsh. The gardens were taking shape both as historical sites and as useful points of reference cropping up in contemporaneous dramatic texts (see Steggle, 2004, pp. 71-74). In her introduction to The Sparagus Garden, Julie Sanders posits that "[ $t$ ]he spatial referents of Brome's play work at a level far deeper than just the locating of the audience in the 'real world'; they offer information of moral, ethical and cultural significance" (Sanders, 2010, n.pag., 12) ${ }^{12}$. In The Sparagus Garden, however, the promised garden of delights is slow to materialise on stage, even though it is an imagined presence throughout the first two acts. The real-world referent is constantly alluded to and discursively (re-)constructed as the various characters try to claim it for their purposes. The first instance in this process of perpetual deferral occurs in the Prologue:

$[\ldots]$ the subject is so low,

That to expect high language or much cost,

Were a sure way, now, to make all be lost.

$[\ldots]$

The title, too, may prejudice the play.

It says 'The Sparagus Garden'. If you look

To feast on that, the title spoils the book.

We have yet a taste of it, which he doth lay

I'th midst o'the journey, like a bait by th' way [...]

(SG, Prologue, speech 2)

A typical instance of the strategy of captatitio benevolentiae, the prologue's initial lines warn the audience not to look for high-flown language or costly spectacle, claiming that the play's "subject is so low." What makes the prologue stand out, however, is the latter part containing an announcement that the play might not even live up to the expectations raised by the title: "[...] If you look / To feast on that, the title spoils the book," which is a slightly belated disclaimer, since the audience have already taken the bait laid by the title and have paid to attend the play. The next two lines assure the audience that

12 In his study on London's built environment, Darryll Grantley states that the playwrights of the later commercial theatre could conveniently fall back on the representation of geographical locality as shorthand for moral qualities, turning them into "moralized landscapes," a convention reaching back to early religious theatre and which would have easily been understood by their audiences (2008, pp. 22-23). 
they will "have yet a taste of it," but the pleasure to "feast" and "taste" of the Sparagus Garden on stage will be deferred to the third act. The choice of verbs in the prologue establishes a semantic and associative nexus which permeates the entire play. The idea of consumption, both in a literal and in a figurative sense, will be varied throughout the play in which food items, the garden space, or the dramatic performance itself will be put up for consumption. The prologue testifies to Brome's finely tuned antennae for his audience's appetite to see representations of fashionable places on stage (see Grantley, 2008, pp. 152-153). Furthermore, Brome demonstrates his awareness of competing on a marketplace for theatrical entertainment where the choice of title may prove a clever move, a marketing strategy to attract large audiences. The prologue also implies that the scope of the play will not be limited to bringing one of the voguish asparagus gardens onto the stage. Conceptualising the play's progress as a "journey," the prologue foreshadows the many trajectories - physical, social, and emotional - the characters will have made by the end of the play.

\section{The Sparagus Garden, London, England and Beyond}

Strategically placed "i'th midst o'the journey," the asparagus garden becomes the key site where various kinds of encounters, exchanges and transformations take place which eventually usher in the plot's final turns towards its dénouement ${ }^{13}$.

A green rural space surrounded by the sprawling city and its encroaching buildings, the garden is invested with a broad range of meanings. Steggle unpacks the rich symbolism of the garden, in which different traditions, drawing on sources ranging from classical mythology to the Bible ${ }^{14}$ and to contemporaneous literature and political di-

13 The importance and extremely careful symmetrical composition of the third act, in which the garden first features as a location, have been analysed at length in Julie Sanders' introduction to the play (2010, n. pag., 22-28) and by Matthew Steggle (2004, pp. 75-81). Their analyses qualify earlier readings which dismissed the third act as a mere sequence of incoherent episodes. An early example of a rather unfavourable reading (not only of The Sparagus Garden, but of most of Brome's plays) can be found in Andrews (1913) who highlights the structural deficiencies of the play which he considers to be nothing more than a series of plot strands, "two of them wholly episodic" (1913, p. 55). He concedes, however, that the episodes staged in the third act are "very realistic tavern-scenes at the doubtful resort known as the Sparagus Garden" (p. 56). In Kaufmann's reading, although not altogether dismissive of the play, the garden itself figures as merely "necessary to unify the various plot elements" (1961, p. 60).

14 For a thorough account of the manifold Biblical motifs and reverberations in The Sparagus Garden, see Frieder Stadtfeld's analysis of the play (1977, pp. 126-176). Stadtfeld traces meticulously the Biblical echoes which permeate the garden scene, and indeed the entire play. He proposes to understand the garden as inherently oxymoronic, challenging the audience with representations of seemingly irreconcilable impulses which turn the place into a 'hellish Paradise' or a 'paradisiacal Hell' (1977, p. 129; translated by Ch.M.). 
scourses, intersect and overlap: the asparagus garden hints at, alternately, the garden Eden that has fallen into the depths of mundane commercial activities, early modern symbolical-political gardens as they are to be found for instance in Shakespeare's plays and the accompanying call to properly tend to the garden state, ${ }^{15}$ the three Graces of classical mythology dancing in some green space, or the classical locus amoenus which could serve as a foil to the mercenary activities of the city and is constantly invaded by its inhabitants (see Steggle, 2004, pp. 81-83). The garden becomes a site where manifold economic and sexual transactions take place and call into question the stability of the characters' identities and social stations (see Van Renen, 2011, pp. 57-58). Apart from the rich symbolism and the dramaturgic function of the garden, the London site is encoded as an arena where economic, social, national and transnational concerns are being addressed and negotiated.

Run by a gardener and his Dutch wife, the business venture of the asparagus garden is situated on inherently unstable ground. A drained area of former marshland, the "very ground is described as lacking in solidity" (Steggle, 2004, p. 75). The garden's material properties and the hint at the Dutch origins of the gardener's wife link it to the Low Countries, whose very existence had been built on "ground that was proverbially unstable, provisional, and heterogeneous" (Steggle, 2004, p. 76). Neither have the couple tending it reached economically solid ground; they are the garden's tenants who work the land and bring in the profits, but they do not own it. However, the gardener affirms that he once wished to buy "this manor of marshland for the resemblance it has to the Low Country soil you came from - to ha' made you a Bankside lady." He adds, not without hope, "We may in time be somewhat" ( $S G$, 3.1. speech 414). Like the rest of the cast, the gardener and his wife are social climbers who wish to exchange the shaky grounds of their tenure for the more solid grounds of ownership and financial security (see Steggle, 2004, p. 76). Treading on these culturally and socially fluid grounds, the guests themselves are in a perpetual state of flux: they move in and out of the fluidly composed garden 'scene,' and some of the characters leave no more than a fleeting impression. Inwardly, most of them are yearning for a transformation, said to be brought about by the miraculous qualities of the garden itself and its main delicacy, asparagus. In the complicated "social dance" (Sanders, 2010, n.pag., 23) the characters perform, they not only try to satisfy their personal and social ambitions but also to lay

15 Richard II comes most readily to mind, in particular the gardener scene in 3.4. with the first servant enquiring

Why should we in the compass of a pale

Keep law and form and due proportion,

Showing, as in a model, our firm estate,

When our sea-walled garden, the whole land,

Is full of weeds, $[\ldots] \quad(\mathrm{RII}, 3.4 .40-44)$ 
claim to the site itself. The garden is thus exemplary of the "contested spaces" which are emerging in the town and which can be claimed physically and discursively. Different groups and individuals, among them the theatre and its professionals, are striving to conceptualise, shape and interpret the sites in question according to their economic, political, or religious agendas (see, e.g., Van Renen, 2011, p. 35). The instability that is rooted in the material properties of the garden turn it into an apposite metaphor for the perceived instability of London and its inhabitants.

In a play whose key setting is on materially and discursively shifting ground, the characters themselves are bound up in negotiations about spatial and social identities which are crumbling before their very eyes. The Sparagus Garden is deeply informed by and aware of the histrionic nature of early modern life and the performativity of social identity which is "also a conscious performance of the self" within "wider networks: of patronage, politics, local identity, manuscript and artistic and theatrical circles, neighbourhoods" (Sanders, 2011, p. 4; p. 5). The play explores the theatricality which permeates the social performances of its characters, controls their relationships and interactions and shapes their understanding of their world. Sir Hugh Moneylacks is the play's central incarnation of the brittleness of social status and the necessity to constantly adapt and re-invent oneself in a society on the move. He has married a rich man's daughter whose dowry he has managed to dissipate in the shortest time. In desperate need of fresh means to support himself, the former knight assumes and casts off different professional and social personas: he is a prospective projector for sedan chairs (see $S G, 1.1$. speech 89), a professional cheat, he acts as sexual advisor to his landlord and -lady, and he is the garden's "gather-guest" (SG, 3.1. speech 436). The protean Sir Hugh evades over-simplified responses and interpretations of the play's social dynamics. Some of his traits can be traced to the stock types of Jacobean city comedy, like the prodigal spendthrift or the shrewd and immoral trickster figure, but any attempt to understand him solely along the lines of his dramatic predecessors would be reductive. Volatile and swiftly adapting to the occasions at hand, Sir Hugh can no longer be assigned to any established social category; his character can no longer be contained within the traditional class system. Crafty and eloquent, Sir Hugh splendidly qualifies for the post of "gather-guest" to bring in custom to the gardener and his wife:

ReBeCCA. [...] Sir Hugh, I will have sparagus every meal all the year long, or I'll make all fly for't. And do you look to't, Fribble, for it will be for your commodity as well as mine.

BRITTLEWARE. And sure it is a rare commodity when a knight is become a broker for to cry it up so.

[...] 
Moneylacks. But mistake not me, nor the commodity we speak of Mistress Brittleware. Where would you have it? Here in our own house? Fie! The virtue of it is mortified if it pass the threshold from the ground it grows on. No, you must thither to the garden of delight, where you may have it dressed and eaten in the due kind. [...]

REBECCA. Is there conveniency for that too?

Moneylacks. Yes, yes; the house affords you as convenient couches to retire to as the garden has beds for the precious plants to grow in. That makes the place a palace of pleasure, and daily resorted and filled with lords and knights and their ladies, gentlemen and gallants with their mistresses -

(SG, 2.1. speeches 214-219)

Sir Hugh's success in marketing the garden and its produce depends on the public's eagerness for the latest fashion, style and luxury goods, here initially ascribed to Rebecca, but then gradually extended to the rest of the cast and therefore constructed as an all-encompassing trait of Londoners. The eagerness for novelty proves instrumental in kindling new yearnings for items and goods which still need to be 'placed' as desiderata with the play's characters and the audience. Sir Hugh's great charm resides in his ability to immediately recognise and respond to the cravings of his interlocutors - in this he resembles the playwright who taps into the market potential of the latest fads. He sells his victims the fiction that the transformations they are yearning for will be most readily accomplished in the Sparagus Garden, through the consumption of asparagus which will work as the catalyst bringing about wondrous transformations. There, he suggests, Rebecca will eventually cast off her state of childless wife and Tim Hoyden will complete his transformation from a young country-man to a fashionable gentleman ( $S G$, 3.1. speeches 655-658). Moreover, Sir Hugh relies on the fact that the garden space is yet as it were culturally unchartered territory and therefore malleable to suit his ends: the garden can be turned into anything, between an actual plot for growing vegetables on the one hand and a "garden of delight" or "palace of pleasure" on the other. In Sir Hugh's praise, the garden is a space open to everyone, "filled with lords and knights and their ladies, gentlemen and gallants with their mistresses," an enumeration which presents the audience with a bewildering juxtaposition of social and moral categories. This vision will prove delusory, since the allegedly socially inclusive garden is in the process of being transformed into yet another socially exclusive space. As one of the young visitors to the garden wryly notes, "these that respect profit merely have not the wit and less the virtue to distinguish betwixt the best and the worst, but by their purses" (SG, 3.1. speech 465). The garden in Brome's play is being converted into a space governed by rules which grant only restricted access to the financially affluent excluding other groups: "access to the gardens and what they represent in the 1630 s eludes the 
otherwise triumphant younger generation" whose preoccupation to mend interfamilial feuds does "not recommend them to the gardeners who capitalize on pleasure-seeking Londoners" (Van Renen, 2011, p. 54).

Several disturbing notes are sounded in the exchange between the aspiring Brittlewares and Sir Hugh. Brittleware's ironic remark that "a knight is become a broker for to cry it [the asparagus] up so" highlights the challenge Sir Hugh's character poses. For all his great comic potential, Sir Hugh is problematic in that he frustrates any attempt to safely assign him to any stable social category. The decayed knight - and here we face the first conundrum, namely the question of whether Sir Hugh came by his knighthood by birth or by purchase - has turned merchant and peddler, crying his ware up and down, reminiscent of the crafty businessmen and -women of Jacobean city comedy and he will turn trickster at the next instant. Even allegedly stable categories such as parenthood have been liquefied, with Sir Hugh forced to renounce his daughter and to turn her over to the care of his father-in-law. The Brittlewares' childlessness renders Rebecca vulnerable to Sir Hugh's dodgy peddling. Their childlessness harks back to other childless couples of earlier city comedies, for instance Sir Oliver and Lady Kix in Thomas Middleton's A Chaste Maid in Cheapside (1613) who enter the stage bickering and quarrelling, blaming each other for their hapless state (Chaste Maid, 2.1). Contrary to them, however, the Brittlewares will not be gleefully expectant at the end of the play, which denies the audience the immediate satisfaction of seeing their expectations fulfilled. Notwithstanding the happy resolution in the last act, regeneration and rejuvenation will have to wait. ${ }^{16}$ Ultimately, the fictions of social advancement, inclusion and transformation which Sir Hugh and the garden's tenants sell are as elusive as the space itself: Rebecca has to acknowledge that her predicament cannot be solved, for "not the 'sparagus can do't, unless the man were better," (SG, 3.1. speech 649), and, unsurprisingly, the aspirant gentleman has to rely solely on the power of "confidence" to believe in the sham that has been his transformation (SG, 3.1. speeches 650-651).

Denis Van Renen has recently pointed out the colonial discourses underlying many of the texts conveniently grouped as 'place realism' plays. Looking beyond the urban landscape of London, he points out that the garden can also be seen as an arena where current rural developments, national expansionist desires and international rivalries are being addressed. In the plays, "these suburban developments were imagined as colonial ventures" which could be placed within the context of "European models of both internal colonialism and New World expansion" (Van Renen, 2011, p. 35). Situated in Lambeth on the Southbank of the Thames, the pleasure gardens' origins in former

16 For the social implications of childlessness, in particular for the wife's standing in the community, see e.g. Mendelson \& Crawford, 1998, pp. 66-69 and 148-164. 
marshland obliquely hint at the numerous projects then in vogue to claim land by fen drainage. The projects of fen drainage, which were marketed as lucrative investment opportunities offering the prospect of spectacular returns, had been targeted in earlier city comedies, notably in Ben Jonson's The Devil is an Ass (1616). Criticism was often mingled with anti-Dutch sentiment since these projects relied on Dutch technologies and expertise and on Dutch workers being brought in to put them into effect. Unsurprisingly, to English sensibilities, fen drainage was highly contentious and ideologically charged and it had disruptive effects on rural communities. At the same time, a certain admiration and ambition spurred English investors who cast an envious eye on the trading networks the Dutch were operating and the economic power they wielded (see Van Renen, 2011, p. 37). Nodding towards Martha's Dutch origins and inserting references to her keeping a "Dutch account" (SG, 3.1. speech 428; 429), Brome's play hints at the Dutch presence in England and at anti-Dutch sentiments. The garden setting is therefore both inward- and outward-looking; it turns our attention on specific developments in London while opening up a European perspective, placing its characters and their city's economy within the wider context of inter-European rivalry for technological and economic pre-eminence.

\section{Bibliography}

Andrews, C.E. (1913). Richard Brome: A Study of his Life and Works. New York: Henry Holt and Company.

Bentley, G.E. (1956). The Jacobean and Caroline Stage. Vol. 3. Oxford: Clarendon.

Boulton, J. (2000). London 1540-1700. In p. Clark (ed.), The Cambridge Urban History of Britain (pp. 315-346). Cambridge: Cambridge University Press.

Brome, R. (1635). The Sparagus Garden, [modern text]. Ed. J. Sanders. Richard Brome Online. Retrieved from http://www.hrionline.ac.uk/brome [accessed 24.02.2017].

Butler, M. (1984). Theatre and Crisis, 1632-1642. Cambridge: Cambridge University Press.

Butler, M. (2006). Exeunt Fighting: Poets, Players, and Impersonators at the Caroline Hall Theaters. In A. Zucker \& A.B. Farmer (eds.), Localizing Caroline Drama. Politics and Economics of the Early Modern English Stage, 1625-1642 (pp. 97-128). New York-Basingstoke: Palgrave.

Grantley, D. (2008). London in Early Modern English Drama. Representing the Built Environment. Basingstoke: Palgrave Macmillan.

Gurr, A. (2004). Playgoing in Shakespeare's London, (3 ${ }^{\text {rd }}$ ed.). Cambridge: Cambridge University Press.

Howard, J.E. (2007). Theater of a City. The Places of London Comedy 1598-1642. Philadelphia: University of Pennsylvania Press.

Kaufmann, R.J. (1961). Richard Brome. Caroline Playnright. New York: Columbia University Press.

Manley, L. (1995). Literature and Culture in Early Modern London. Cambridge: Cambridge University Press. 
Mendelson, S. \& Crawford, p. (1998). Women in Early Modern England, 1550-1720. Oxford: Oxford University Press.

Middleton, T. (2007). A Chaste Maid in Cheapside. Ed. L. Woodbridge. In G. Taylor \& J. Lavagnino (eds.) Thomas Middleton: The Complete Works (pp. 907-958). Oxford: Oxford University Press.

Miles, T. (1942). Place-Realism in a Group of Caroline Plays. The Review of English Studies, vol. 18, no. 72, pp. 428-440.

Peck, L.L. (2000). Building, Buying, and Collecting in London, 1600-1625. In L.C. Orlin \& L. Cowen (eds.), Material London ca. 1600 (pp. 268-289). Philadelphia: University of Pennsylvania Press.

Porter, R. (1996). London. A Social History. London: Penguin.

Sanders, J. (2010). The Sparagus Garden. Critical Introduction. Richard Brome Online. Retrieved from https://www.hrionline.ac.uk/brome/viewOriginal.jsp?play=SG\&type=CRIT [accessed 20.02.2017].

Sanders, J. (2011). The Cultural Geography of Early Modern Drama. 1620-1650. Cambridge: Cambridge University Press. https://dx.doi.org/10.1017/CBO9780511762260.

Shakespeare, W. (2015). The Life and Death of King Richard the Second. In S. Greenblatt et al. (eds.), The Norton Shakespeare (pp. 885-956). New York: Norton.

Stadtfeld, F. (1977). Die Karolinische Ortskomödie. Studien zur nachelisabethanischen und vorrestaurativen Dramatik. Heidelberg: Winter.

Steggle, M. (2004). Richard Brome. Place and Politics on the Caroline Stage. Manchester: Manchester University Press.

Van Renen, D. (2011). A 'Birthright into a New World': Representing the Town on Brome's Stage. Comparative Drama, vol. 45, no. 2, pp. 35-63.

Zucker, A. (2011). The Places of Wit in Early Modern English Comedy. Cambridge: Cambridge University Press. 